\title{
Tourism and the Economy of Nigeria: A synthesis of its contributions to GDP from 2005-2016
}

\author{
Murtala Mohammed Alamai \\ Leisure and Tourism Department, Federal polytechnic Bauchi \\ Mohammed Uwais Hussaini \\ General Studies Department, Federal polytechnic Bauchi
}

Aliyu Ladi Fatima

Hospitality Management Department, Kaduna Polytechnic Kaduna

\begin{abstract}
For many emerging economies tourism is the export earner, including several Least Developed Countries (LDCs) such as Burkina Faso, Gambia, and Nigeria because tourism has proved to be a strong and resilient economic activity that contributes to the economic recovery of nations through generation of billions of dollars in income while also stimulating job creation for destinations across the globe. In view of that, this paper is a theoretical review of the direct, indirect and induced impact of tourism to the economic development of Nigeria over a period of 16 years from the emergence of the millennials. The paper observes that Nigeria as a country has the potentials of making tourism a main source of its earnings being that it has a diverse tourist attractions, a large domestic tourist market, an upcoming middle class which can reinvigorate domestic tourism and unique cultural settings capable of enticing foreign tourists though there is no political will to implement and sustain its tourism policies and actions which can translate into economic gains for its citizens. The paper recommends among other things the entrenchment of sound tourism development master plan capable of rejuvenating the potentials in the economic blueprint of the country and ensuring sustainable tourism development participation even in the face of difficulties and uncertainties. The paper employs the Desk Study approach as its methodology.
\end{abstract}

Key Words: Economy, Tourism synthesis, Earnings, GDP.

\section{INTRODUCTION}

Nigeria's economy in the past ten years showed signs of a strong emerging market but also exhibited common vulnerabilities of a resource-based economy. The country posted strong annual growth rates of above $6 \%$ from 2007-2010 and then slowed to $2.7 \%$ in 2015 before a decline in the first quarter of 2016, followed by a further drop in the second and quarter to signal the beginning of a first economic recession since 1991(Fritova Economics 2017) Even though the united nations world tourism organization (UNWTO) in its world barometer (2015) has it that tourism has proved to be a strong and resilient economic activity that contributes to the economic recovery of nations through generation of billions of dollars in income while also stimulating job creation for destinations across the globe.

Furthermore, in UNWTO (2014) annual report it observed that tourism gained ground in 2014 with intensified support by governments and the international community recognizing the sector's contribution to socioeconomic growth, development and employment. Schwab and Sala-i-Martín, (2015) in world economic forum insights of global competitiveness advanced 
that the picture for Nigeria is mixed based on efficiency of the goods market (100th), where a less competitive domestic environment outweighs improvements to encourage foreign competition, and the labor market, being one of the region's most flexible (18th) is dragged down by an inefficient use of talent (68th) thus holding the country back from fulfilling its potential.

The richness and diversity of Nigeria's culture has always been cited as strong reason why tourism should be a major foreign exchange earner for the country. From east to west, from north down to south, the country is naturally endowed with rich tourist sites like the Osun Osogbo Groove, Sukur Cultural Landscape in Adamawa, Obudu Cattle Ranch, Ogbunike Cave, Oguta Late, Yankari Game Reserve, Olumo Rock, Idanre Hills, Ikogosi Waterfall, Mambila Plateau etc. the list is inexhaustible, including those that are yet to come to limelight.

Also, when it comes to festivals, Nigeria is not lacking. From the Argungu Fishing Festival, to Osun Osogbo Festival, Abuja Carnival, Calabar Christams Carnival, Cross Rivers State Carnival, Eyo Festival, Igue Festival, Ojude Oba Festival, Badagry Festival, Durbar Festival, almost every state in the country hosts one or more festivals yearly

\section{STATEMENT OF THE PROBLEM}

In most countries of the world, travel and tourism is an important economic activity. Aside from its direct economic impact, the sector has significant indirect and induced impacts. Despite wars, political turmoil, natural disasters, medical scares, terrorist attacks, and economic and energy crises in various parts of the world, international trade in tourism services has grown spectacularly since the 1970s. Unfortunately, years after, the Nigerian Tourism Master Plan, which would have set the tone for a holistic development of the sector, is still lying on the government shelf. Amid discordant tunes from stakeholders, implementing the plan suddenly became a herculean task, with scanty activities thriving in the sector. And with the oil money still flowing, the plan was almost forgotten. If there's any takeaway from the country's current economic distress, it is the fact that both individuals and government are becoming creative, as they grapple with wealth and job creation. With the downturn owing to devastating fall in the price of crude oil, it has become very crucial for the country to go beyond rhetoric and grandstanding in the quest to develop the tourism sector.

\section{OBJECTIVE OF THE STUDY}

The Nigerian Tourism industry has experienced significant growth over the last decade, and the country as a travel destination is becoming an increasingly popular choice for many both domestically, regionally and international. There are however, several challenges which affect the ability of sector service providers in the industry to meet customer expectations. The main aim of the study was therefore to obtain firsthand information about the state of tourism in the Nigerian economy, its contributions to GDP, employment, jobs, wealth creation and on how to improve overall service delivery in the industry.

The study was developed to achieve the following:

1. Identify current industry trends

2. Assess Which sectors of the industry performs in the nation

3. Highlight areas of strengths and weaknesses of the industry in the economy of Nigeria

\section{METHODOLOGY}

The study employed a desk approach system by reviewing literature available on tourism and the Nigerian economy while analyzing the impact, use and its contributions to the growth of the economy as well as its contributions to GDP, directly or induced. 


\section{TOURISM CONTRIBUTIONS TO EMERGING ECONOMIES (NIGERIA)}

For many emerging economies tourism is the export earner, including several Least Developed Countries (LDCs) such as Burkina Faso, Gambia, Haiti, Madagascar, Nepal, Rwanda and Tanzania. Tourism generated US\$ 485 billion in exports for emerging economies in 2013, being the fourth export earner (UNWTO 2014). In same vein, world travel and tourism council (WTTC 2017) see Travel \& Tourism as an important economic activity in most countries around the world. As well as its direct economic impact, the industry has significant indirect and induced impacts. Kolawole (2017) advanced that Nigeria as a country needs to re-evaluate our sheer reliance on crude oil. Matter-of-factly, the government must have learnt a great lesson from the recession. Dependency on one major source of income is bad for a growing economy like ours with a population that grows on an average of $2.3 \%$ yearly. We are yet to develop another sector to have little parity in terms of revenue being generated. While Frivota Economics (2017) sees the demand for leisure activities, social activities and outdoor relaxation facilities like music, art, entertainment, movies etc. is emerging as a major opportunity for investment because for about 30 months from 2105 to early 2017, the rapid and largely sustained slump in commodity (especially crude oil) prices, and significant disruptions to both crude oil production and agricultural activity in sections of the country, have combined to unmask the soft underbellies of Africa's largest economy. The National Bureau of statistics (2013) also stated that between 2011 -2012 the Hotel and restaurant sector in Nigeria contributed between $12.01 \%$ to $12.69 \%$ to the total GDP of the country and it is expected to increase as the years increase too.

\section{NIGERIA'S TOURISM DEVELOPMENT}

Nigeria had her first international tourists in 1472, when Portuguese merchants visited Lagos, apparently in search of trade. There are also historical records of Trans-Saharan and caravan movements. Since then, the tourism industry has continued to show appreciable growth in the country. In 1962, the Government established the Nigerian Tourist Association (NTA) and charged it with the responsibility of promoting domestic and international tourism in the country (Munzali 2011). In 1976, NTA was dissolved and the Nigerian Tourism Board (NTB) established in its place. The development of the sub-sector was boosted in 1990, when the Ministry of Trade and Industry was created, and the NTB became a Corporation (Ashikodi 2010). The significance of tourism lies in its great potentials for generating foreign exchange. For example, according to Central Bank of Nigeria (CBN 1988), a total of 328,906 tourists arrived in Nigeria in 1987 and the receipt earned was N1.1 billion. Estimated earnings were expected to reach some N53 billion by the year 2000, and much higher by 2005, particularly given the stabilizing democratic dispensation in the country (Yusuf and Akinde2015).

By 2017 the government seeing the need for diversification of the economy having witnessed recession and fall in oil prices introduced a new vis policy that aims at easing access to the country for business as well as to boost tourism within the overall context of the administration's economic diversification agenda (This day 2017). Quoting the minister of information and tourism Lai Mohammed, on Nigerian Television Authority news of February 26 2017, Justice (2017) said

"Types of visas currently reviewed include Visa on Arrival (VOA) processes, Business Visas, Tourist Visas and Transit Visas. Mohammed further explained that "Business Visas are available for foreign travelers who wish to travel to Nigeria for meetings, conferences, seminars, contract negotiation, marketing, sales, purchase and distribution of Nigerian goods, trade fairs, job interviews, training of Nigerians, emergency/relief work, crew members, staff of NGOs, staff of INGOs, researchers and music concerts". 
Furthermore, International center for investigative reporting (ICRI 2017) quoted the comptroller of immigration Mohammed Babbandede saying

"Tourist visas are also available to foreign travelers who wish to visit Nigeria as tourists or to visit family and friends".

While the visit on arrival (VOA) is a class of short visit visa issued at the port of entry and is available to frequently-travelled high net-worth investors and intending visitors who may not be able to obtain visas at Nigerian missions/embassies in their countries of residence due to the absence of a Nigerian mission in those countries or the exigencies of urgent business travel.

CONTRIBUTIONS OF LEISURE AND TOURISM TO NIGERIA'S ECONOMY 2005-2016.

In an analysis of Nigeria's strength and potentials, Kolawole (2017) believes the country has an advantage of population. In fact, if we can sell tourism to just Nigerians to a point where they can see the value proposition, it might become optional to sell to foreign tourists. we have the numbers, and the percentage of our population that has the purchasing power for tourism is above $30 \%$, out of over 180 million Nigerian.

Taking a look at the statistics of fact sheet (2016) of the record of tourism receipts (International tourists) to the country, (figure 1) it will be observed that there has been a steady increase from 2005 to 2010 but after which there is a decline of revenue from international tourists before it picked up from 2015.

Figure 1. International Tourists Receipts in Nigeria 2005-2015

\section{Nigerias International Tourist Receipts 2005-2015}

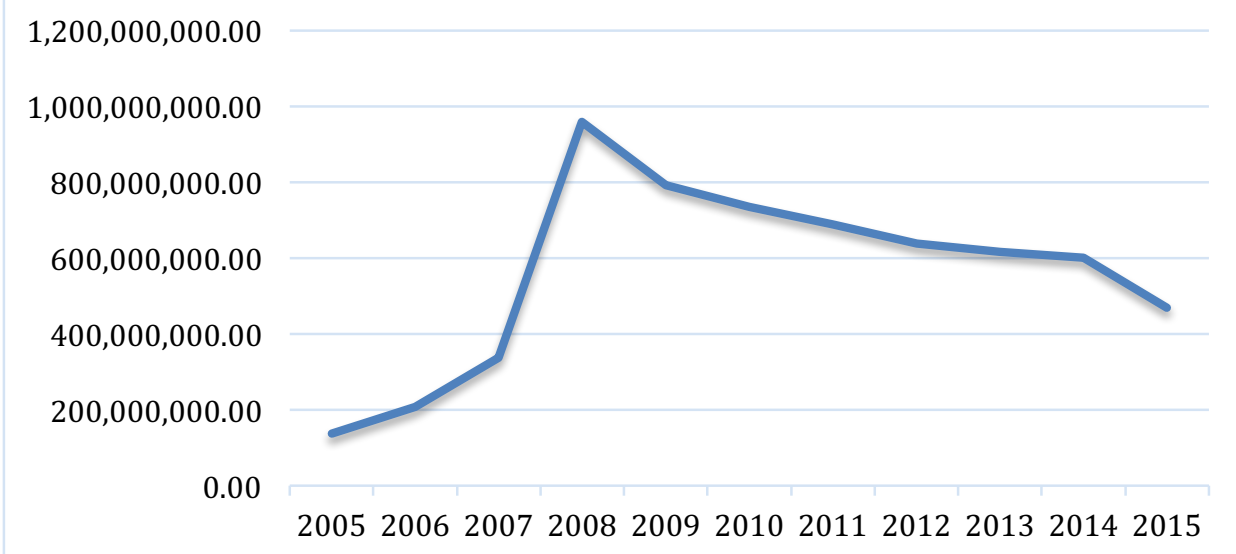

Source: Source: Adapted from World Bank group (2018)

International tourist's receipts were at a peak between 2008-2009 with great spending's coming into the country however we experienced declining revenue from end of 2010 through 2011 to 2015 as a result of global economic meltdown, terrorist's activities increasing all over the world, menace of boko haram and kidnappings in Nigeria etc.

Furthermore, when you look at the arrivals by international tourist to the country within same period as shown in figure 2 corresponds well with the flow of tourists into the country 


\section{Number of International Tourist Arrivals in Nigeria 2005-2015}

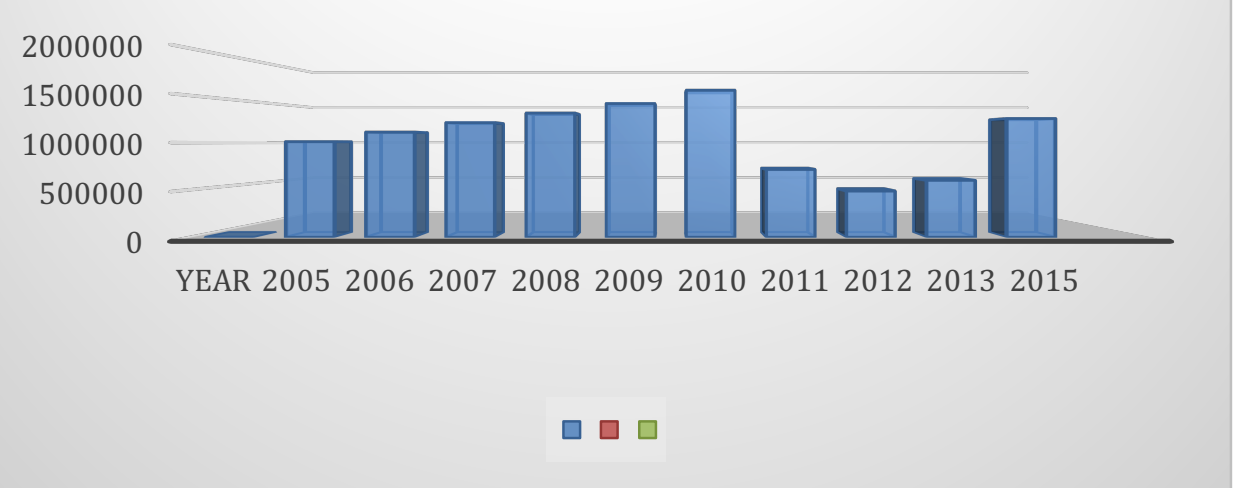

Source: Source: Adapted from World Bank group (2018)

It will be observed from figure 2 above there was a steady increase in number of international arrivals from 2005 with a peak at 2010 while there was a sharp decline in 2011 which could be attributed to the 9/11 terrorist attack and the global economic meltdown however by 2015 there was a resurgence due to a lot of business conferences held in the country and a smooth democratic handover after what seems a hazy image of situation in the country.

Equally when looking at the percentage change in quantum of arrivals to the income generated in millions figure 3 shows a slight variance where arrivals ratio to percentage of income varies significantly over the years steadily normal then a great fall from 2010 through 2011 to 2013 then showing a steady increase towards 2015 as explained earlier due to stability of the polity and government structures in the country.

Figure 3. International arrivals percentage to income generated 2005-2015

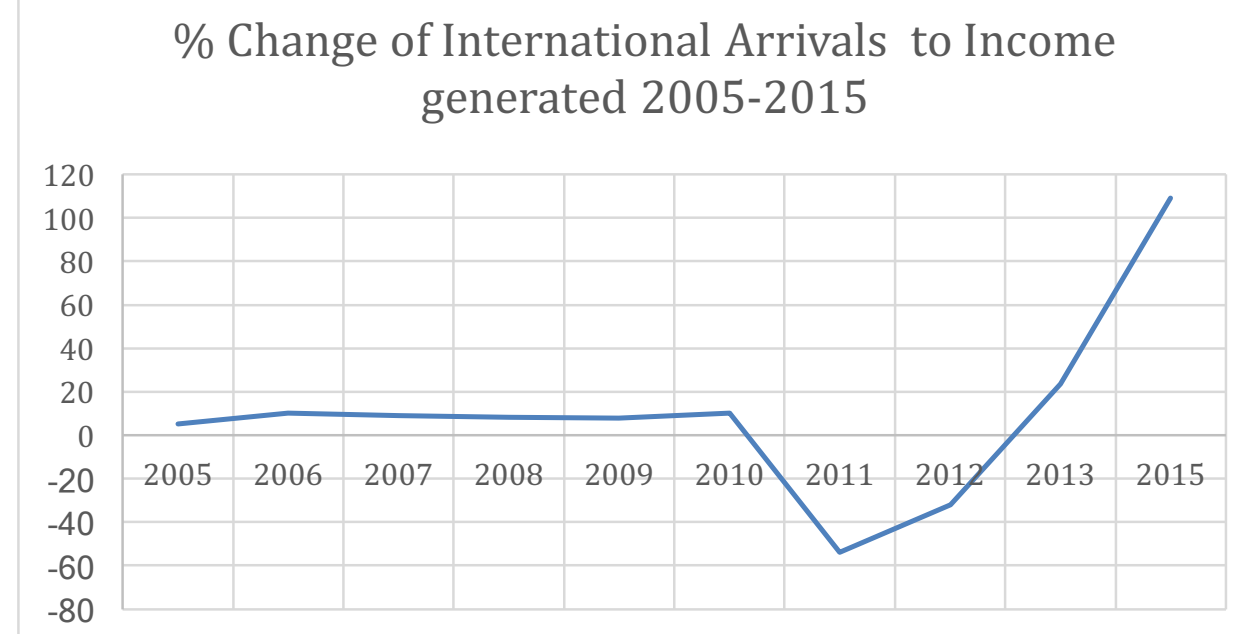

Source: Adapted from World Bank group (2018)

However, going by sector breakdown of the world travel and tourism council statistics of 2017 the contributions of the domestic tourism sector to the economy based by sectors of the industry are as follows 
1. Leisure travel spending (inbound and domestic) generated $54.1 \%$ of direct Travel \& Tourism GDP in 2016 (NGN1,668.7bn) compared with $45.9 \%$ for business travel spending (NGN1,417.1bn).

2. Domestic travel spending generated $93.2 \%$ of direct Travel \& Tourism GDP in 2016 compared with $6.8 \%$ for visitor exports (i.e. foreign visitor spending or international tourism receipts).

3. Visitor exports are a key component of the direct contribution of Travel \& Tourism. In 2016, Nigeria generated NGN211.3bn in visitor exports. In 2017, this is expected to fall by $2.8 \%$, and the country is expected to attract 733,000 international tourist arrivals.

4. Travel \& Tourism have attracted capital investment of NGN1,129.4bn in 2016.

5. Travel \& Tourism generated 649,500 jobs directly in 2016 (1.6\% of total employment) this includes jobs in hotels, travel agents, airlines and other passenger transportation services (excluding commuter services). It also includes, for example, the activities of the restaurant and leisure industries directly supported by tourists.

However, (WTTC 2017) further highlighted that the total contribution of Travel \& Tourism to employment (including wider effects from investment, the supply chain and induced was 1,793,000 jobs in 2016 (4.5\% of total employment). And The total contribution of Travel \& Tourism to GDP (including wider effects from investment, the supply chain and induced income impacts was NGN5,124.3bn in 2016 (4.7\% of GDP) See Table 1

Table 1. Summary tables, estimates and forecasts for tourism growth and contributions to Nigeria's economy

\begin{tabular}{|l|c|c|c|}
\hline Nigeria & $\begin{array}{c}\mathbf{2 0 1 6} \\
\text { US bn }\end{array}$ & $\begin{array}{c}\mathbf{2 0 1 6} \% \text { of } \\
\text { Total }\end{array}$ & $\begin{array}{c}\text { 2017 Growth } \\
\text { Estimates }\end{array}$ \\
\hline Direct contribution to GDP & 7.4 & 1.7 & 1.1 \\
\hline Total contribution to GDP & 20.3 & 4,7 & -1.3 \\
\hline Direct contribution to employment & 649 & 1.6 & 3.4 \\
\hline Total contribution to employment & 1.793 & 4.5 & 1.4 \\
\hline Visitor exports & 0.8 & 2.1 & -2.8 \\
\hline Domestic spending & 11.4 & 2.7 & 1.4 \\
\hline Leisure spending & 6.6 & 0.9 & 0.4 \\
\hline Business spending & 5.6 & 0.8 & 1.9 \\
\hline Capital investment & 4.5 & 7.2 & -5.0 \\
\hline
\end{tabular}

Source: WTTC Nigeria Outlook (2017)

The percentage of total in the table refers to each indicator's share of the relevant whole economy indicator such as GDP and employment while visitor exports is shown relative to total exports of goods and services. Domestic spending is also expressed relative to whole economy GDP. For leisure and business spending, their direct contribution to Travel \& Tourism GDP is calculated as a share of whole economy GDP (the sum of these shares equals the direct contribution). Investment is relative to whole economy investment. Equally the real price economic contributions of travel and tourism to the economy from 2011 to 2016 is shown in table 2 below 
Table 2: Real Price index of Travel and Tourism Contributions to Nigerian Economy 2011-2016

\begin{tabular}{|c|c|c|c|c|c|c|}
\hline Nigeria Real price in NGN bn & 2011 & 2012 & 2013 & 2014 & 2015 & 2016 \\
\hline 1. Visitor exports & 153.1 & 132.8 & 120.9 & 113.6 & 104.9 & 211.3 \\
\hline $\begin{array}{l}\text { 2. Domestic expenditure (includes } \\
\text { government individual spending }\end{array}$ & 2300.3 & 2538.4 & 2777.1 & 2885.3 & 2862.9 & 2874.5 \\
\hline 3. Internal tourism consumption $(=1+2)$ & 2453.4 & 2671.2 & 2898.0 & 2998.9 & 2967.8 & 3085 \\
\hline $\begin{array}{l}\text { 4. Purchases by tourism providers, } \\
\text { including imported goods (supply chain. }\end{array}$ & 981.0 & $-1,061.4$ & $-1,138.9$ & $-1,181.4$ & $-1,181.1$ & $-1,224.3$ \\
\hline $\begin{array}{l}\text { 5. Direct contribution of Travel \& Tourism to } \\
\text { GDP }(=3+4)\end{array}$ & $1,472.4$ & $1,609.8$ & $1,758.2$ & $1,817.5$ & $1,786.8$ & $1,861.4$ \\
\hline $\begin{array}{l}\text { 6. Other final impacts (indirect } \& \\
\text { induced) Domestic supply chain }\end{array}$ & 879.8 & 961.9 & 1.050 .6 & $1,086.0$ & $1,067.7$ & $1,112.3$ \\
\hline 7. Capital investment & 790.5 & 832.6 & 993.5 & $1,079.9$ & $1,134.1$ & $1,129.4$ \\
\hline 8. Government collective spending & 19.6 & 19.8 & 18.3 & 17.7 & 19.0 & 18.2 \\
\hline 9. Imported goods from indirect spending & -574.0 & -507.9 & -233.4 & -130.5 & -157.8 & $-155,8$ \\
\hline 10. Induced & 705.9 & 823.8 & $1,035.3$ & $1,109.4$ & 1.109 .1 & $1,158.9$ \\
\hline $\begin{array}{l}\text { 11. Total contribution of Travel \& Tourism } \\
\text { to GDP }(=5+6+7+8+9+10)\end{array}$ & $3,294.2$ & $3,740.1$ & $4,622.5$ & $4,980.0$ & $4,958.8$ & $5,124.3$ \\
\hline $\begin{array}{l}\text { 12.Employment Impacts }(* 000) \\
\text { Direct contribution of Travel \& Tourism } \\
\text { to employment }\end{array}$ & 630.9 & 596.4 & 661.1 & 659.6 & 634.9 & 649.3 \\
\hline $\begin{array}{l}\text { 12. Total contribution of Travel \& Tourism } \\
\text { to employment. }\end{array}$ & $1,397.5$ & $1,397.9$ & $1,752.0$ & $1,820.5$ & $1,774.3$ & $1,792.8$ \\
\hline $\begin{array}{l}\text { 13. Other indicators } \\
\text { Expenditure on outbound travel }\end{array}$ & $1,525.0$ & $1,393.8$ & $1,309.5$ & $1,295.3$ & $1,557.8$ & 482.2 \\
\hline
\end{tabular}

\section{Source: WTTC Nigeria Outlook (2017)}

From table 2 above there is a yearly increase in number of people participating in domestic tourism and internal spending on tourists services and products rising at an approximately 3$4 \&$ annually from 2011 to 2016 which can be attributed to increase in awareness of the value of domestic tourism as well as investment in the sector there by contributing to the directly to the country's GDP as shown from 2011 at 1,472.4 bn NGN to 1,861.4bn NGN in 2016.Equally too is the sectors contribution towards employment generation over the years both skilled, non-skilled, semi-skilled and induced jobs from the services that are offshoots of the industry rose from 1,397.5 in 2011 to 1,792.8 in 2016 reaching about an increase of 14\% within 5 years

\section{CONCLUSIONS}

In conclusion, Nigeria's economy can and needs to derive full benefits from the knowledge it possesses through the right application of the knowledge, conversion of such knowledge into viable ideas and commercial implementation of such ideas into use for both local and international value chain use. Also, from the foregoing there exits avenues where leakages occur due to spending outside the country by nationals travelling for either government related activities or vacations.

\section{RECOMMENDATIONS}

The study will thus recommend the followings to the government, industry practitioners and academia

1. To the government at all levels, there needs to be a shift in the education dynamics in three ways of: First there needs to be a strong working tie between the academia (Primary custodians of Knowledge) and the industry (Primary users of knowledge).

2. The government at all levels needs to make investor protection shift from institutional uncertainty to established order not just in policy statements but actions of its employees because emerging market investors are mostly concerned with the level of 
protection that the operating environment offers such as clarity of economic policies, application and institutional enforcement of rules etc.

3. Government collective spending needs to increase locally to stimulate growth and the economy mostly as it relates to conferences, workshops and incentive trips.

\section{References}

Ashikodi, T.I. (2010). Tourism Development in the coastal region of Nigeria: Economics of Tourism development a shift from oil dependence. From http://www.worldculturelink.org

Fritova Economics (2017) Nigeria in 2017: Seeing beyond the recession. Available from: www.businessdayonline.com. Accessed 04/02/2018.

International center for investigative reporting(ICRI) (2017). Nigeria Announces, 'Visa on Arrival' Policy for Foreign Investors. Available from: https://icirnigeria.org/. Accessed 10/10/2017

Justice, E. (2017) Federal Government Introduces New Visa Policy. Available from http://www.nta.ng/news/diplomacy.

Kolawole.O. (2017). Understanding the Economics of Tourism in Nigeria. Available from: http://govandbusinessjournal.com.ng. Accessed 9/7/2017.

Munzali,D (2011). Tourism development in Nigeria: challenges and prospects for resource diversification. Available from: https://www.scribd.com/doc/53329130. Accessed 10/03/2018.

National Bureau of Statistics (2013) Economic outlook for the Nigerian economy (2013-2016)

Schwab, K and Sala-i-Martín, X. (2015). World economic forum: The Global Competitiveness Report 20152016.Available from: www.weforum.org/gcr.

This day (2017) Nigeria Eases Entry Visa for Foreigners. Available from https://www.thisdaylive.com. Accessed 9/7/2017

UNWTO Annual Report 2014. Published by the World Tourism Organization (UNWTO), Madrid, Spain. First printing: (2015) www.unwto.org. 6/10/2016.

World Tourism Organisation (2015) UNWTO world tourism barometer. 13. ISSN 1728-9246. Available from: www.unwto.org. Accessed 15/10/2016.

World Travel and Tourism Council (2017) Report on Travel \& Tourism economic impact 2017 Nigeria. Available from: https://www.wttc.org/-/media/files. Accessed 12/06/2017.

World Bank group (2018) International Tourism, number of arrivals. Available from https://data.worldbank.org/indicator/ST.INT.ARVL?locations=NG. Accessed 10/03/2018

Yusuff, M. A. and Akinde, M. A (2015). Tourism development and economic growth nexus Nigeria's Experience. European Journal of Hospitality and Tourism Research.3(4) 1-10 